DOI: https://doi.org/10.47405/aswj.v6i3.173

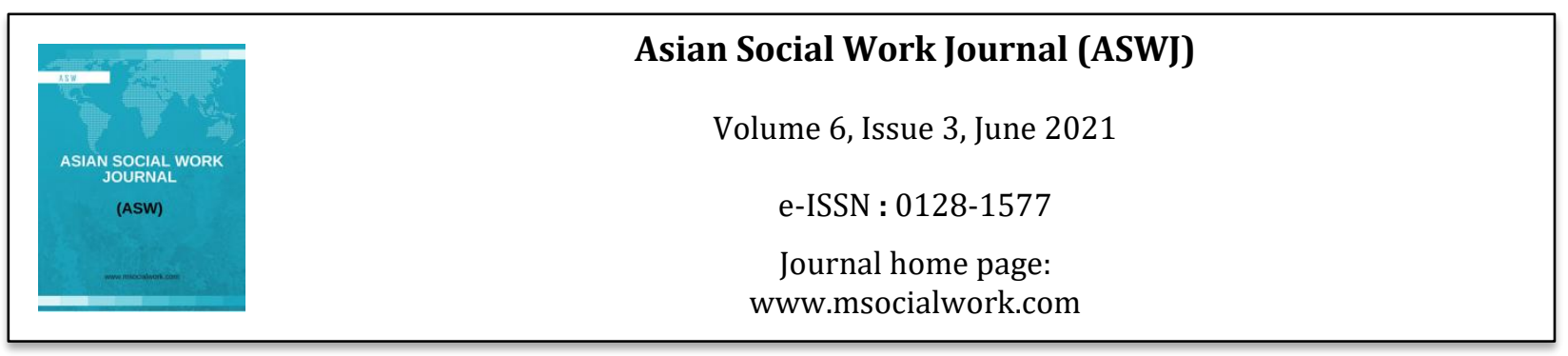

\title{
Development of Naga Village Traditional Community: An Empowerment Based Islamic Education Model
}

\author{
Toto Wiradisastra ${ }^{1}$, Masyitoh ${ }^{1}$, Gofur Ahmad ${ }^{1}$ \\ ${ }_{1}^{1}$ Muhammadiyah Jakarta University, Indonesia \\ Correspondence: Toto Wiradisastra (toto@envilab.id.com)
}

\begin{abstract}
The purpose of this study is to identify and analyze Islamic education which is the basis for increasing empowerment in all aspects of the Kampung Naga indigenous community that has been carried out, so that from the results of this research a new pattern can be made, namely: developing a model for the empowerment of the Kampung Naga indigenous community based Islamic education. The field survey research method is descriptive qualitative using an ethnographic approach, using primary data sources through interviews with traditional leaders; religious leaders; tour guides and representatives of community members in Kampung Naga and added secondary data sources in the form of: documents; archives and records. Data analysis used qualitative data analysis with the Miles and Huberman model then continued with the preparation of the final research report. The results of the study found that: community empowerment in the Kampung Naga area that had been given by the government included: empowerment in the field of tourism/culture; empowerment in the field of entrepreneurship/craft; empowerment in the field of natural resource management and the environment as well as religion. From the results of the research, the existing model of empowerment of the Kampung Naga indigenous community based on Islamic education can be developed more broadly covering the following aspects: economy; environment; health; and division of roles. Meanwhile, supporting factors for good empowerment are: government support; involve local residents; and public participation. So from the steps mentioned above, the aspects of the results of empowerment through religious education are: the spiritual soul there is an increasing change; good member entrepreneurship spirit; charity-service to the citizens who are weak smoothly distributed; Devotion to a strong country.
\end{abstract}

Keywords: development, indigenous peoples, Islamic education, economy, environment, health, role sharing, empowerment

\section{Introduction}

Islamic education aims to develop humans and society as a whole and comprehensively. Islamic education is always based on the values of divinity, humanity and nature. For human life, the direction of Islamic education is to be able to build, develop, and bring blessings to all other creatures. Therefore, Islamic education can develop the ability to build life and realize various human skills. To realize the concept of human responsibility in Islamic education today in formal and informal educational institutions, the type of community-based education in the informal education sector can be in the form of community empowerment, or in other words community empowerment through educational activities 
DOI: https://doi.org/10.47405/aswj.v6i3.173

and one of them is religious education. Community empowerment is an effort to improve sustainable long-term welfare, with an emphasis on community values. Meanwhile, Suryadi stated that community empowerment is an effort to improve human skills and competencies for knowledge, attitudes and skills for self-existence, as well as being able to participate and improve their position in society. In addition to education, community strengthening is also determined by socio-cultural factors (Suryadi, 2006:24). In the Islamic concept. Community empowerment in the social field is aimed at preventing discrimination between tribes, religions and tribes in social life, because Allah SWT hates people who discriminate between fellow beings. Meanwhile, in terms of culture as a product of society, it is closely related to moral values. Every product of society is closely related to the issue of moral values which are the embodiment of divine values in the Qur'an.

Being a blessing for all nature means growing and cultivating values so that all social activities are not only for personal interests, but also for the needs of the community and also the entire community. The culture contained in the teachings of Islam is not lost from the essence of the purpose of human creation, because culture is the way of human existence that includes all human capabilities that Allah SWT has given. The purpose of human creation is to obey Allah SWT.

This community empowerment has to do with remote indigenous communities that focus on social empowerment according to Presidential Regulation no. 186 of 2014 concerning Social Empowerment for Remote Indigenous Communities and also in the context of implementing the provisions of Article 23 paragraph 3 of Government Regulation Number 39 of 2012 concerning the Implementation of Social Welfare. According to the Ministry of Social Affairs R.I. (2003), the empowerment program for remote indigenous communities is a program that is directed at efforts to give authority and trust to communities with remote categories. Through this program, the community can identify problems and needs and solve them based on their respective strengths and abilities, thereby improving the quality of life, protecting and upholding their fundamental rights in the local culture. The empowerment program for remote indigenous peoples is expected to improve the social welfare of residents after the program is implemented. Social welfare includes various actions that people take to achieve a better standard of living in a broad sense. This standard of living is measured economically and physically, but by considering aspects of socio-cultural, spiritual and psychological life (Adi, 2003).

This community empowerment is carried out in order to overcome the poverty that occurs, where the poverty in question does not only cover material problems, but also non-economic problems. Due to its multidimensional nature, poverty is not only related to social welfare. The definition of poverty from several dimensions consists of: poverty with economic dimensions, poverty with socio-cultural dimensions and poverty with political or structural dimensions. This community empowerment program has been implemented by the government at all levels of society, including Kampung Naga. This village describes a village that is home to a group of people who are very closely related to the traditional culture of their ancestors, in this case the Sundanese order.

Kampung Naga is a traditional village whose nature is still natural. The community still clings to their ancestral traditions and always refuses outside interference, which can affect or damage the sustainability of the village. Kampung Naga maintains its customs along with changes in the surrounding community from time to time. Its existence shows the real life of Indonesian society that is not contaminated by cultural changes. As a local community, the residents of Kampung Naga, Tasikmalaya Regency are very interesting to study. The village has developed relatively slowly in recent decades but is able to regulate itself with strict rules and strengthen its way of life. Their consensus on Islamic rules and traditional rules from generation to generation is quite harmonious

Furthermore, from the aspect of education, the residents of Kampung Naga have a level of education in the majority reaching the elementary school level, although there are also those who are able to continue their education to a higher level, but not many. While informal education in Kampung Naga, from Monday-Friday at 2 (two) afternoon there is always a recitation for children. On average, their thinking patterns are still not broad so they seem to think why they should go to high school if they eventually return to their villages, their principle is that in school it is important to be able to read, write and count, and even then, they are sufficient in their opinion. With this assumption, parents think it is better to learn 
DOI: https://doi.org/10.47405/aswj.v6i3.173

from nature and experience or groups in mosques or halls in general, with this assumption being a separate obstacle for the government to include formal education in the Kampung Naga community. In addition, the low level of education is caused by a lack of socialization in the field of education and there must be special and directed efforts by the government to advance Kampung Naga.

If it is related to Islamic education, the basic problem is that most of the people of Kampung Naga even though they are Muslim, still mix cultural elements with Islamic teachings, with the level of understanding about Islamic education being not deep, even though it is known that community empowerment can be done with a good level of education. Islamic education was born as a cultural institution created by the initiative of community leaders (Sulisno, S and Abdullah, A, 2019:73-82). As for Islamic education, it is an integration of the values of Aqeedah, Shari'ah, and Morals. With the existence of Islamic education, empowerment of the community will be carried out, especially in the social and cultural aspects in accordance with the scope of Kampung Naga as an indigenous community and also the existing phenomena. There, the indigenous people of Kampung Naga still adhere to traditional traditions in the form of cultural heritage and social events. Inheritance makes it impossible for parents to transmit evil, and as a social phenomenon, tradition binds and strengthens the social bonds in which traditions grow, live and thrive.

For Islamic education, if it is related to the words of experts, one of which is according to Muhammad Athiya Al-Abrasyi, the purpose of Islamic education is to prepare people to live perfectly and happily, love their homeland, physically fit, perfect in character (morals), regular thoughts, smooth feelings, proficient in his work, sweet in speech both orally and in writing (Abu Muhammad Iqbal, 2015:566).

\section{Discussion}

\section{Kampung Naga Indigenous People}

Kampung Naga is a small village, one of the traditional villages whose people still follow traditional traditions from generation to generation, which makes this village unique and different from other villages. It is not wrong if this village is part of the cultural heritage of the Indonesian nation that deserves to be preserved. They reject foreign culture when they can destroy the traditional customs of their ancestors. The area of Kampung Naga is about 1.5 ha, a large part of which is used for residential purposes, yards, ponds and the rest for rice cultivation which is harvested twice a year. Currently there are 113 buildings including houses, mosques, bale kampung (community meeting hall), Bumi Ageung (large house, windowless building used to collect heirlooms and used for traditional events) and Leuit (public rice barn).

The population of Kampung Naga society until now there are 301 people, consisting of 101 heads of families, 101 housewives, 3 widowers, 18 widows and 78 who are not yet family including toddlers. From educational background, up to now those who live in Kampung Naga consist of 25 elementary school graduates, 14 junior high school graduates, 11 senior high school students and 2 undergraduate students, the others did not finish elementary school, but none of them were illiterate.

The government system in Kampung Naga comes from 2 (two) organizations: formal and non-formal, or state and custom. The government includes RT, RW and Kadus. To make a decision, they usually consult with a traditional institution consisting of Kuncen (caretaker), Lebe (who deals with religion) and Punduh (protects the community).

\section{Islamic Education}

The implementation of education, especially Islamic education in the Kampung Naga community, consists of two forms, namely formal and informal. Formal education is the same as in other places, carried out in schools in a structured manner, while informal education in the Kampung Naga community is through recitations delivered by the ulama every Monday night and Thursday night for 
DOI: https://doi.org/10.47405/aswj.v6i3.173

children and Friday nights for adults, especially fathers and mothers, it is done after Maghrib prayer. Children are taught ethics and customs, this informal education has a very important role as the cultivation of customs in Kampung Naga. In addition, religious education is obtained in the family environment. The function of education in the family is to become a bridge between the impact of advances in science and technology and the socio-cultural environment. By fostering good moral values, the younger generation can transform and realize these values in their daily lives.

\section{Relationship with Economy}

Islam requires its people to be able to meet all the needs in their lives through hard work so that their economic life is prosperous, they are assigned to adjust their work according to their skills and abilities. However, Islam requires norms so that people who do business in the economic field do not conflict with Islamic law itself, such as: comparable, realistic, fair, responsible, sufficient and focused on humans in accordance with their rights as caliphs on earth. These basics prove that economic empowerment in Islam is the opportunity for every member of society to get prosperity, which ultimately feels the favors and gifts of Allah SWT (Khoirul Anwar, 2008).

Regarding the economy, the people of Kampung Naga have carried out their activities and implemented them in the fields of: (1) agriculture, the community carried out rice planting activities in the fields with a harvest period of twice a year, of which $70 \%$ was used for their daily needs while $30 \%$ was deposited/ stored in the granary as a backup in case of crop failure. In addition, they plant secondary crops, medicinal plants as well as fish, chicken and sheep/goats. (2) handicrafts, using sticks, bark, animal skins, bamboo, rattan, and wood as the basic materials for making them. From the results of this craft produced in the form of bags, hats, bamboo baskets, stick plates, slippers, kitchen utensils, flutes, other unique crafts and production related to the needs of traditional events. They do this work in addition to filling their spare time after doing their main job, with the results of this craft the people of Kampung Naga also get economic added value by the presence of local and foreign tourists who come and buy these crafts; (3) tourism, with the existence of the Kampung Naga Tour Guide Association (HIPANA), many local residents join and are involved as tour guides. In addition to understanding the history of Kampung Naga, there are several important things that need to be considered related to the applicable customary rules. To assess the performance of the behavior of the tour guide, the HIPANA chairman periodically evaluates the results of his performance, this is done to always maintain local wisdom. For the tour guides, this is certainly a job opportunity and an increase in the welfare of life.

\section{Relationship with Environment}

The people of Kampung Naga have divided the land use into three areas, namely: (1) the sacred area, a small hill where their ancestors are buried and the people of Kampung Naga; (2) clean area, pollutionfree area in which there are settlements, aging earth, bale patemon, mosques and rice granaries; (3) dirty areas, there are bathing facilities, toilets, cattle pens, huts and ponds.

The other environment consists of: (1) protected forest which is one of the sources of life whose sustainability is maintained; (2) irrigation, consisting of three springs, namely river water; absorption water and well water; (3) a settlement consisting of a resident's house and other facilities.

\section{Relationship with Health}

Regarding health problems, the people of Kampung Naga have tried to live clean and healthy lives. For traditional treatment using plants that are efficacious as medicine, generally planted / located around the yard of the house, the edge of the pond / rice fields and other plantation land. There are 51 species of plants that are efficacious as medicines, the use of which is in the form of leaves $(74.08 \%)$, roots $(11.11 \%)$ and fruit $(5.56 \%)$. The use of leaves is more widely used because the leaves will be easier to grow than the roots and fruit. Distribution of medicinal plants, in the garden (52.95\%), in the yard (35.29\%) and the edge of the fields/ponds (11.76\%). (Source: Journal of Pharmacy Galintika Vol.02 No.01 ISSN: 2406-9299). 
DOI: https://doi.org/10.47405/aswj.v6i3.173

Treatment for the elderly, pregnant women and toddlers is the first step to using traditional medicine, but if it still doesn't heal or needs further treatment, you can seek treatment at the Clinic outside the Kampung Naga area.

\section{The division of roles}

The division of roles is very important to always maintain the preservation of customs, economic fulfillment, environmental management, health, development and education in Kampung Naga. In the division of roles, of course, it must involve the government sector, in this case the local government and the community itself.

From the explanation above, it can be seen that the fulfillment of one's material needs can improve the welfare of the community. In addition, the tranquility and comfort felt by the community with the empowerment of the community through Islamic education is another indicator that can show the spiritual welfare of the community. So it can be seen that community empowerment carried out by the government together with traditional and religious leaders provides a form of material and spiritual adequacy.

While departing from the basic constraints and solutions in the concept of community empowerment, namely the lack of knowledge, mindset and practice is still weak. Where empowerment is a process to change the condition of the people who experience the lack of empowerment. These efforts are intended to make the community more empowered through the knowledge provided so that they become a more independent society. From the results of the study, it can be seen that the obstacles that arise regarding the community's initial knowledge about the empowerment program can be overcome by providing socialization and training carried out by the government together with traditional and religious leaders through Islamic education who participate directly in the community to introduce related to the meaning and the purpose of the empowerment program itself. This is the same as the first stage of empowerment, namely awareness and behavior formation towards conscious behavior of the need to increase selfability or capacity.

\section{Conclusion}

After analyzing all the data from the field research and other data that the researchers have done regarding the Development of the Kampung Naga Community Empowerment Model Based on Islamic Education, the following conclusions can be drawn:(1) community empowerment in the Kampung Naga area that has been provided by the central government in collaboration with the regional government and related agencies, among others, is the empowerment of the tourism/culture sector, the empowerment of the entrepreneurship/crafts sector to support the economy, the empowerment of the management of natural resources and the environment, by holding training / seminar / technical guidance as well as the manufacture of other supporting facilities and infrastructure; (2) Islamic education in Kampung Naga is divided into: formal education obtained from schools and informal education, namely education carried out/given by parents, elders, traditional elders and kiai during weekly recitations. The previous teaching process could not be separated from the role of traditional leaders. Indigenous leaders have the power and authority to control and monitor every member of their community. The traditional leader continues to carry out one of his duties, namely compliance and obedience to the rules / provisions / guidelines that are passed down from generation to generation.(3) Community empowerment based on Islamic education in Kampung Naga has not been optimally realized by the government, because there are slight differences in the rules used in implementing Islamic education, with the customary rules originating from their previous ancestors. In addition, the role of traditional leaders and religious leaders is still strong in the rules used related to Islamic education and its application in empowering the Kampung Naga community.

To be able to develop the empowerment of the Kampung Naga indigenous community based on Islamic education, further research is necessary because:(1) the empowerment of indigenous peoples in Kampung Naga is not yet known holistically; (2) there is no complete research data on Islamic education 
DOI: https://doi.org/10.47405/aswj.v6i3.173

for the indigenous people of Kampung Naga; (3) publicity regarding the empowerment of indigenous peoples in Kampung Naga through religious education is still minimal.

\section{References}

Abdul Mujib dan Jusuf Mudzakir, Ilmu Pendidikan Islam (Kencana Prenada Media Group, Jakarta, 2014), h. 13.

Abdurrahman al-Nahlawi, Ushul al-Tarbiyah al-Islamiyyat wa Ashalibiha, yang diterjemahkan oleh Shihabuddin dengan judul Pendidikan Islam di Rumah, Sekolah dan Masyarakat (Gema Insani Press, Jakarta, 1995), dalam Mappasiara, 2018, Pendidikan Islam (Pengertian, Ruang Lingkup dan Epistemologinya), Volume VII, Nomor 1, h. 20

Abdullah Zakiy Al Kaaf, Ekonomi dalam perspektif islam. (Pustaka Setia, Bandung, 2002). h. 29

Abu Hurairah, Pengorganisasian \& Pengembangan Masyarakat (Humaniora, Bandung, 2011), h. 87

Abu Muhammad Iqbal, Pemikiran Pendidikan Islam "Gagasan-gagasan Besar para Ilmuwan Islam” (Pustaka Pelajar, Yogyakarta, 2015), h. 566

Achmadi, Ideologi Pendidikan Islam (Pustaka Pelajar, Yogyakarta, 2005), h. 29

Abidin Ibn Rush. Pemikiran Al-Ghazali Tentang Pendidikan Islam (Pustaka Pelajar, Yogyakarta, 1998), h. 60

Adi Fahrudin, Ph. D, Pemberdayaan, Partisipasi dan Penguatan Kapasitas Masyarakat, (Humaniora, Bandung, 2012), h. 16

Adi, I. R., 2003, "Pemberdayaan, Pengembangan Masyarakat dan. Intervensi Komunitas". (Pengantar Pada Pemikiran dan Pendekatan Praktis), Jakarta: Lembaga Penerbit FEUI, Cet 1

Agus Ahmad Syafi'I, Menejemen Masyarakat Islam, (Gerbang Masyarakat Baru, Bandung, 2019), h.70

Ahmad Munjih dan lilik Nurholidah, Metode dan Teknik Pembelajaran Pendidikan Agama Islam (PT. Refika Aditama, Bandung, 2013), h. 63

Ahmad dan Talib, 2014. Analysis of Community Empowerment on Projects Sustainability: Moderating Role of Sense of Community, Social Indicators Research, ISSN 0303-8300, Soc Indic Res, DOI 10.1007/s11205-014-0781-9.

Al-Rasyid, G., 2017. Urgensi Pendidikan Orang Dewasa dalam Pemberdayaan Masyarakat Adat $\begin{array}{llll}\text { Kampung Naga. } & \text { TARBAWI, } & 4(1), & 37-59 .\end{array}$ https://doi.org/https://doi.org/10.36781/tarbawi.v4i1.2913

Amir, FR., dan Nasution, SA., Pemberdayaan Masyarakat Melalui Kegiatan Pendidikan, Agama, Sosial, Ekonomi, Dan Kesehatan, Qardhul Hasan: Media Pengabdian kepada Masyarakat ISSN 2442-3726 Volume 3 Nomor 1, 2017

Andi Prastowo, Metodologi Penelitian Kualitatif Dalam Perspektif Rancangan Penelitian (Ar-ruzz Media, Yogyakarta, 2012), h. 220

Ani, F. dkk. Applying Empowerment Approach In Community Development (Jurnal University Tun Hussein Onn Malaysia, Johor, Malaysia, 2017), h. 506

Anwas, O. Pemberdayaan Masyarakat di Era Global (Alfabeta, Bandung, 2014), h. 58

Armai Arief, Pengantar Ilmu dan Metodologi Pendidikan Islam (Ciputat Pers, Jakarta, 2002), h.16

Bachrudin, et.al., 2018. Community Empowerment In Planning Local Wisdom-Based Development. International Journal of Humanities, Religion and Social Science, ISSN : 2548-5725 Volume 2, Issue 12.

Bancin, M, Peningkatan Partisipasi Masyarakat Dalam Program Nasional Pemberdayaan Masyarakat (PNPM) Mandiri Perdesaan (Studi Kasus: Bandung Barat). Jurnal Perencanaan Wilayah Dan Kota, 22(3), 2011, h. 182

Creswell, John W, Research Design Pendekatan Kualitatif,. Kuantitatif, dan Mixed (Pustaka Pelajar, Yogyakarta, 2012), h. 462

Dahana. OP and OP. Bhatnagar, Education and Communication for Develompment. (Oxford \& IBH Publishing CO, New Delhi, 1980), h. 46

Douglass, S. L., \& Shaikh, M.A. (2004). Defining Islamic education: Differentiation and application. Current Issues in Comparative Education, 7(1), 5-18.

Dwidjowijoto dan Wrihatnolo, Manajemen Pemberdayaan: Sebuah Pengantar dan. Panduan untuk Pemberdayaan Masyarakat (PT. Elex Media Komputindo, Jakrta, 2007), hh. 30-33 
DOI: https://doi.org/10.47405/aswj.v6i3.173

Edi Suharto, Membangun Masyarakat Memberdayakan Rakyat: Kajian Strategis Pembangunan Kesejahteraan Sosial dan Pekerjaan Sosial, (Refika Aditama, Bandung, 2009), h. 59

Gade, A.M., 2012. "Tradition and Sentiment in Indonesian Enviromental Islam." in Worldviews: Environment, Culture and Religion, Vol. XVI, Issue 3 (2012), p. 263 - 285.

Hadiyanti, P., 2009. "Pemberdayaan Masyarakat Adat Terpencil Melalui Model Pendidikan Luar Sekolah". Jurnal Ilmiah VISI PTK-PNF - Vol. 4, No.2.

Hamid, A.L., 2018. Perilaku Keberagamaan Masyarakat Kampung Naga Dalam Perspektif Teori Religious Behavior Marie Cornwall, al-Afkar. Journal for Islamic Studies, Vol. 1, No.1, January 2018E-ISSN :2614-4905, P-ISSN :2614-4883.

Hanif, M.I., dan Mutakin, Z., 2019. Community Empowerment Model Based on Islamic Education Institutions. Al-hayat Journal of Islamic Education (AJIE), Volume 3, Issue 1.

Haris, A, Memahami Pendekatan Pemberdayaan Masyarakat Melalui Pemanfaatan Media (Jurnal Jupiter, 2014),13(2), h. 52.

Islam Digest Republika, Awal Mula Islam Masuk ke Ranah Minang, https://www.republika.co.id/berita/dunia-islam/islamdigest/19/03/11/po7c98458-awal-mulaislam-masuk-ke-ranah-minang (2019), h.32

Yulong $\mathrm{Li} \&$ Caroline Hunter, Community involvement for sustainable heritage tourism: a conceptual model. (Journal of Cultural Heritage Management and Sustainable Development, 5(3), 2015), hh. 248-262.

Karwati L. dan Mustakim, M., 2018. Model Pemberdayaan Masyarakat Terintegrasi Dengan Kearifan Dan Nilai Budaya Lokal Melalui Pendekatan Sosial Entrepreneurship. Jurnal Ilmiah Visi, 13(2), 157 - 164. https://doi.org/10.21009/JIV.1302.9.

Kurniawan, I.D., dan Suryono, H.. 2018, Peran Pendidikan Terhadap Eksistensi Kehidupan Masyarakat Adat Kampung Naga, Tasikmalaya, Jawa Barat. PKn Progresif, Vol. 13 No. 1 Juni 2018.

Malik, A., \& Mulyono, S. E, Pengembangan Kewirausahaan Berbasis Potensi Lokal melalui Pemberdayaan Masyarakat.(Jurnal of Nonformal Education and Community Empowerment Vol.1 No.1, 2017), h. 88

Matthoriq, dkk, Aktualisasi Nilai Islam Dalam Pemberdayaan Masyarakat Pesisir (Studi Pada Masyarakat Bajulmati, Gajahrejo, Kecamatan Gedangan, Kabupaten Malang), Jurnal Administrasi Publik (JAP), 2014. Vol. 2, No. 3, h. 427

Mardikanto, Totok \& Soebianto, Poerwoko, Pemberdayaan Masyarakat Dalam Perspektif Kebijakan Publik (Alfabeta, Bandung, 2019), hh. 26-27

Margayaningsih, Pemberdayaan Masyarakat Desa Sebagai Upaya Penanggulangan Kemisikinan (Publiciana, 2016, Vol 29 No. 1). hh. 166-168

M. Arifin, Filsafat Pendidikan Islam (PT Bumi Aksara, Jakarta, 1987), h. 11

Moleong, Lexy. J, Metodologi Penelitian Kualitatif Edisi Revisi (PT. Remaja Rosdakarya, Bandung, 2016), h. 186

Miles M.B, Huberman AM, Qualitative Data Analysis (SAGE Publishing Inc, Los Angeles, 2014), h.14

Muhaimin, Paradigma Pendidikan Islam (PT Remaja Rosdakarya, Bandung, 2002), h. 37

Mulyono, S. E, Kemiskinan dan Pemberdayaan Masyarakat (Ombak., Jakarta, 2017), h. 46

Ningrum, E., 2012. Dinamika Masyarakat Adat Tradisional Kampung Naga di Kabupaten Tasikmalaya. Jurnal Mimbar, 28(1):47-54.

Nur Uhbiyati, Ilmu Pendidikan Islam. (Pustaka Setia, Bandung, 1996), hh . 30-31

Qodariah dan Armiyati. 2013, Nilai-Nilai Kearifan Lokal Masyarakat Adat Kampung Naga Sebagai Alternatif Sumber Belajar, Socia - Jurnal ilmu-ilmu sosial, Vol. 10 No.1.

Ramayulis, Metodologi Pendidikan Agama Islam (Kalam Mulia, Jakarta, 2010), h.2- 3

Rayan, S., 2012. Islamic Philosophy of Education. in International Journal of Humanities and Social Science Vol. 2, No. 19 October 2012, p. 150.

Rita Pranawati dan Irfan Abubakar., Pemberdayaan Masyarakat untuk Pembangunan Perdamaian, (Center for the Study of Religion and Culture (CSRC) Universitas Islam Negeri (UIN) Syarif Hidayatullah Jakarta, 2009, Cet. Ke-1, h. 70

Rosmedi, Riza Risyanti, Pemberdayaan Masyarakat, (Alqaprit Jatinegoro, Bandung, 2006), h.1

Safrudin Aziz, Pemikiran Pendidikan Islam (KALIMEDIA, Yogyakarta, 2015), h.168.

Salleh, M.S., 2013. Strategizing Islamic Education. in International Journal of Education Research Vol. 1, No. 6 June 2013, p. 4. 
DOI: https://doi.org/10.47405/aswj.v6i3.173

Setiawan, 2015, President Jokowi Signed Presidential Regulation Remote Indigenous Community Empowerment, https://setkab.go.id/en/president-jokowi-signed-presidential-regulation-remoteindigenous-community-empowerment/

Sugiyono, Memahami Penelitian Kualitatif (Alfabeta, Bandung, 2009), h. 2

Sulisno, S., dan Abdullah, A., 2019, Islamic Education and Community Empowerment, International Journal of Education and Learning ISSN 2684-9240, Vol. 1, No. 2, hh. 73-82

Sunartiningsih, A, Memberdayakan Masyarakat Desa Melalui Institusi Lokal (Aditya Media, Yogyakarta, 2004), hh. 77-78

Suryadi, A, Mewujudkan Masyarakat Pembelajar : Konsep,Kebijakan dan Implementasi, (Widya Aksara Press, Jakarta, 2006), h. 24

Susilo, A., 2016. Model Pemberdayaan Masyarakat Perspektif Islam. FALAH: Jurnal Ekonomi Syariah, Vol. 1, No. 2, Agustus 2016

Sutopo, Metodologi Penelitian Kualitatif (Sebelas Maret University Press, Surakarta,2002). h. 50

The Heart of Islam: Enduring Values for Humanity and The Garden of Truth: The Vision and Promise of Sufism, Islam"s Mystical Traditional (Seyyed Hossein Nasr, Pesan-Pesan Universal Islam untuk Kemanusiaan, terj. Nuasiah Fakih Sutan Harahap, (Mizan, Bandung, 2003), h. 339-340

Tomi Hendra, "Pemberdayaan Masyarakat dalam Perspektif Al Qur'an", (dalam Jurnal Sosial Vol. 9 No. 02, Desember 2017), h. 31

Ulfi Putra Sany, Prinsip-Prinsip Pemberdayaan Masyarakat dalam Perspektif Al Qur'an, Jurnal Ilmu Dakwah, 2019, Volume 39 No.1, hh. 32-44

Wrihatnolo, R. R., \& Dwidjowijoto, R. N, Manajemen Pemberdayaan: Sebuah Pengantar dan Panduan untuk Pemberdayaan Masyarakat (PT Gramedia, Jakarta, 2007), hh. 2-7

Yasin, Raudlotul Firdaus Binti Fatah. And Jani, Mohd. Shah., 2013. "Islamic Education: The Philosophy, Aim, and Main Features". International Journal of Education and Research., Vol. No. 10.

Zakiah Derajat, dkk, Pendidikan Islam Keluarga dan Sekolah (PT Remaja Rosdakarya, Bandung, 1995), hh. 19

Zuhairini, Metodologi Pembelajaran Pendidikan Agama Islam (UIN Press, Malang, 2004), h. 1 